To cite this article: Anna Planas Lladó, Lídia Feliu Soley, Rosa Maria Fraguell Sansbelló, Gerard

Arbat Pujolras, Joan Pujol Planella, Núria Roura-Pascual, Joan Josep Suñol Martínez \& Lino Montoro Moreno , Assessment \& Evaluation in Higher Education (2013): Student perceptions of peer assessment: an interdisciplinary study, Assessment \& Evaluation in Higher Education, DOI:

10.1080/02602938.2013.860077

To link to this article: http://dx.doi.org/10.1080/02602938.2013.860077

\title{
Student Perceptions of Peer Assesment: An Interdisciplinary Study
}

- Anna Planas Lladó (corresponding autor)

Department of Pedagogy, University of Girona

Girona, Spain

Sant Domènec, 9, 17071, Girona anna.planas@udg.edu

- Lídia Feliu Soley

Department of Chemistry, University of Girona

Girona, Spain

- Rosa Maria Fraguell Sansbelló

Department of Geography, University of Girona

Girona, Spain

- Gerard Arbat Pujolras

Department of Chemical and Agricultural Engineering and Food Technology,

University of Girona

Girona, Spain

- Joan Pujol Planella,

Department of Chemical and Agricultural Engineering and Food Technology,

University of Girona

Girona, Spain

- Núria Roura-Pascual

Department of Environmental Sciences, University of Girona

Girona, Spain

- Joan Josep Suñol i Martínez

Department of Physics, University of Girona

Girona, Spain

- Lino Montoro Moreno

Department Mechanical Engineering and Industrial Construction, University of Girona Girona, Spain 


\begin{abstract}
Peer-assessment provides students with multiple benefits during their learning process. The aim of our study is to examine students' perception of peer-assessment. Questionnaires were administered before and after the peer-assessment process to 416 students studying eleven different subjects in four different fields taught at the University of Girona. Results suggest that students have a positive predisposition towards this methodology, both before and after its implementation. Students perceive it as both a motivating and recommended methodology that facilitates the acquisition of learning at different levels. As for its limitations, students highlight the responsibility that comes with it and a certain amount of distrust in fellow students' abilities to peerassess.
\end{abstract}

Keywords: assessment, peer-assessment, students' perception, higher education, learning

\title{
Introduction
}

The European Higher Education Area proposes a new paradigm: focusing on skills training and learning-centred discourses and practices. This new perspective has led to changes at both a methodology and assessment level. Student assessment has moved on from the traditional testing of knowledge to the culture of learning assessment. Within the assessment culture, students should have an active role in the learning and assessment processes (Lindblom-Ylänne, Pihlajamäki and Kotkas 2006). Despite an increase in literature and practices in recent years, making assessment part of the curriculum continues to pose a real challenge in higher education (Taras and Davies 2012). 
Among the assessment systems to be considered in this new framework it is worth highlighting peer-assessment. Peer-assessment is a system that has been gradually implemented at universities and is used increasingly as an alternative evaluation method (Vickerman 2009; Wen and Tsai 2006). As Topping argued (2009, 20-21), it is an arrangement for learners to consider and specify the level, value, or quality of a product or performance of other equal-status learners. It is a tool for summative evaluation, focusing on learning as a finished product and used to qualify students to complete a course (validation and accreditation). It is also a tool for formative evaluation, as it facilitates the assimilation and progressive development of contents and skills, and the detection of learning capacities acquired by students (support of teaching and learning) (Cestone, Levine and Lane 2008). Peer-assessment is more than students grading their peers' work, as it forms part of a learning process where different skills are developed (Lindblom-Ylänne, Pihlajamäki and Kotkas 2006).

Numerous studies have found that peer-assessment provides several benefits for the learning process. It favours not only student participation and autonomy, but also their taking responsibility for their own learning. Other benefits are: improving student motivation, helping to develop a better understanding, encouraging in-depth learning, control and autonomy of the process of learning, treating assessment as part of the learning process (mistakes are seen as opportunities rather than failures), and increasing the capacity for critical analysis (Boyle and Nicol 2003; Cavas et al. 2010; Dochy, Segers and Sluijsmans 1999; Lindblom-Ylänne, Pihlajamäki and Kotkas 2006; Nicol and Macfarlane-Dick 2006; Topping 2009; Topping et al. 2000; Van der Berg, Amiraal and Pilot 2007; Vickerman 2009; Wen and Tsai 2006). Involving students in assessment processes contributes to their empowerment and provides them with skills for their professional development and lifelong learning.

Despite the positive aspects detected in these practices, some authors also point to weaknesses to be taken into account when applying an evaluation system of this kind. These include: the accuracy and validity of feedback from fellow students, students' insecurity regarding their peers' evaluation, the difficulty of awarding a mark, and the tendency of learners to over-mark or under-mark (Boud and Holmes 1995; Topping 2009; Wen and Tsai 2006). According to Vickerman (2009), the tendency to over-mark usually occurs in cases where students had no anonymity and were reluctant to be seen 
to be penalizing their fellow students. If the processes of evaluation and marking are already difficult for teachers, they will be no less so for students, who have less knowledge and experience in this field.

\section{Students' perceptions of peer-assessment}

In addition to the reported benefits and drawbacks of peer-assessment, some studies have also been published on students' perceptions of it. These studies have shown that peer review has contributed favourably to the learning process, improving quality, and making students feel more motivated and involved in the subject (Cavas et al. 2010; Dochy, Segers and Sluijsmans 1999; Gatfield 1999; Levine 2008; Lindblom-Ylänne, Pihlajamäki and Kotkas 2006; Paswan and Gollakota 2004; Topping et al. 2000; Vickerman 2009; Wen and Tsai 2006). Below, we provide a detailed description of the results of some studies regarding students' perception of peer-assessment.

In studies where student participation in peer-assessment processes focused on marking an essay or written assignment, students perceived that the activity had brought increased confidence and enhanced subject knowledge, as well as appreciation of the intricacies of assessing their own and peers' work. One study that confirms this perception is that conducted by Vickerman (2009), which explores the perceptions and experiences of 90 level-two undergraduate sports students, and involved the formative peer-assessment of two annotated bibliographies. This study showed that students assessing the work of their peers are sometimes engaged in a cognitively demanding activity that broadens their understanding of the subject matter. In relation to this process of formative assessment, around $60 \%$ of the students considered that peerassessment had helped them acquire a greater sense of the assessment process. In another study conducted by Falchikov (1986) on a combined formative and summative experience involving peer, self and tutor-assessed essays, the 48 participants considered that self and peer-assessment made them think, learn more and be more structured than some tutor-based assessments. According to this author, among those aspects that stand out most positively are provision of an outline as an aid to writing the essay and increased awareness and benefits of reading a peer essay. With the aim of confirming the results of previous studies, Hanrahan and Isaacs (2001) carried out a study on students' perception of self and peer-assessment, with the participation of 233 students 
from a third-year tertiary health psychology subject (peer-assessment of a 1,500 word research essay). The qualitative approach used by Hanrahan and Isaacs in their study provides more details regarding the benefits and drawbacks students see in peer and self-assessment. These authors analysed students' perceptions on the basis of an inductive content analysis, which revealed eight general dimensions: difficulty, gained better understanding of marking, discomfort, productive, problems with implementation, read others work, developed empathy, and motivation. These findings were confirmed by Lindblom-Ylänne, Pihlajamäki and Kotkas (2006), who involved 15 law students in a formative exercise aimed at peer and self-assessment of essays. Students saw the process of peer-assessment as positive and felt that a peer's assessment of their own essay was fair, although some students found it difficult to be critical towards a peer.

Regarding students' perception of summative peer-assessment in oral presentation skills, De Grez, Valcke and Roozen (2012) recorded the perceptions of 57 university students enrolled on a Business Administration introductory course to psychology. The results show a very positive attitude towards the value of peer-assessment and a high degree of learning from feedback. Langan et al. (2008) drew the same conclusions from structured interviews with 12 students participating in the summative peer/self assessment of oral presentations on a residential field course. All respondents believed that both self and peer-assessment were very useful experiences that incite reflection. However, some of the students also noted the difficulty of concentrating knowing that fellow students were assessing them.

Having presented the positive aspects, we shall now consider how peer-assessment may be perceived as negative. In several cases, students state that this type of evaluation has hindered their relationships with peers and criticized the lack of objectivity in fellow students' assessments (Hanrahan and Isaacs 2001; Cavas et al. 2010; Lindblom-Ylänne, Pihlajamäki and Kotkas 2006). In some cases, they also see a drawback in not being able to defend their work before the assessor, as observed in a study involving four different subjects and a total of 340 students on different degree courses at the University of Málaga, Spain, in which students had to self and peer-assess answers to practical exercises and problems in a formative and summative peer-assessment process (Cavas et al 2010). Another aspect highlighted by students participating in activities 
related to peer and self-assessment essays is the difficulty involved in this type of work (Falchikov 1986). Furthermore, students' preferences regarding assessment do not always equate with their perceptions regarding the appropriateness of peer-assessment. In his review of peer-assessment research, Topping (2009) noted that students' acceptance of peer-assessment is quite independent from their knowledge of the demonstrated reliability and validity of that assessment. One of the most important aspects is their relationship with their peer-assessment colleagues. Students tend to increase/decrease the mark depending on the context and their personal relations. What is more, their perception can change during the overall process.

\section{Objectives and Methodology}

With the aims of contributing to a better understanding of students' perceptions regarding peer-assessment and proposing improvements in its use, the University of Girona's Network of Educational Innovation in Evaluation, comprising professors from different disciplines and four different faculties and centres (Education, Humanities, Science and Engineering), conducted a study on the perceptions of university students who participated in processes of peer-assessment throughout the 2011-2012 academic year. The main objective of this paper is to analyse students' perception of the peerassessment process before and after participating in it, reflecting on its benefits and suggesting modifications for its improvement.

The study was performed in eleven subjects from eight different degree courses at the University of Girona, with the participation of 416 students. Most students had no previous experience of peer-assessment (only students of Complementary Technology Training had some previous experience). The activities were carried out in three Social Sciences, one Humanities, three Engineering and four Science subjects, with groups varying in size from 13 to 84 students. The peer-assessment activity was organized differently in each subject. The main characteristics of each activity are presented in Table 1 and are based on the contributions of Topping (1998), Gielen, Dochy and Onghena (2011) and Van den Berg, Admiraal and Pilot (2007). With regard to the product and following the criteria used by Gielen, Dochy and Onghena (2011), who divide peer-assessment objects into artefacts (answers to a test, posters, writings, 
presentations, reports) and observed behaviour (cooperative skills, communication skills, social skills, etc.), seven of the peer-assessment activities can be categorized as observed behaviour and four as artefacts. Only one is a draft version, which means the assessee still has the opportunity to revise their work before the final assessment.

With regard to the aims of the peer-assessment (Gielen et al. 2011), six of the activities have the dual aim of learning and assessment, two assessment and active participation, two learning and learning how to assess, and one learning, assessment and active participation. In relation to "direction" of assessment, the activities were categorized as follows: eight mutual (assessment of each other between more than two people or groups), two reciprocal (bilateral assessment between two people or groups), and one unidirectional (from assessor to assessee but not the reverse). Only in two cases is assessment anonymous (the assessor does not know who the assessee is, and the assessee does not know by whom he or she is being assessed). In seven activities the groups or students work on different topics but assess the same skills (courses where students assess oral presentations), in three activities the object of assessment belongs to the same thematic area of the subject, and in one activity each group of students assesses a different thematic area of the subject. To add weight to the work of student assessment, in each subject the score awarded by peers was worth $1 \%$ to $12.5 \%$ of the final mark. 
Table 1. Overview of the 11 subjects considered in the study

\begin{tabular}{|c|c|c|c|c|c|c|c|c|c|c|c|}
\hline Course & $\begin{array}{l}\text { University } \\
\text { student } \\
\text { learning }\end{array}$ & $\begin{array}{c}\text { Project } \\
\text { Design and } \\
\text { Strategies for } \\
\text { educational } \\
\text { action }\end{array}$ & $\begin{array}{l}\text { Complement } \\
\text { s of } \\
\text { technology }\end{array}$ & $\begin{array}{c}\text { Geography of } \\
\text { tourism }\end{array}$ & $\begin{array}{c}\text { Farm } \\
\text { mechanisatio } \\
n\end{array}$ & $\begin{array}{l}\text { Marketing of } \\
\text { agricultural } \\
\text { products }\end{array}$ & $\begin{array}{c}\text { Water and } \\
\text { wastewater } \\
\text { management }\end{array}$ & $\begin{array}{l}\text { Integrated } \\
\text { scientific } \\
\text { techniques III }\end{array}$ & $\begin{array}{l}\text { Chemistry of } \\
\text { the organic } \\
\text { compounds }\end{array}$ & $\begin{array}{c}\text { Social and } \\
\text { legal aspects } \\
\text { of } \\
\text { biotechnolog } \\
y\end{array}$ & $\begin{array}{l}\text { Heterocyclic } \\
\text { chemistry } \\
\text { and drug } \\
\text { synthesis }\end{array}$ \\
\hline Subject & $\begin{array}{c}\text { Social } \\
\text { Education }\end{array}$ & $\begin{array}{c}\text { Social } \\
\text { Education }\end{array}$ & $\begin{array}{c}\text { Master in } \\
\text { Teaching } \\
\text { Training }\end{array}$ & Geography & $\begin{array}{l}\text { Agricultural } \\
\text { Engineering }\end{array}$ & $\begin{array}{l}\text { Agricultural } \\
\text { Engineering }\end{array}$ & $\begin{array}{l}\text { Mechanical } \\
\text { Engineering }\end{array}$ & $\begin{array}{l}\text { Environmental } \\
\text { sciences }\end{array}$ & Chemistry & Biotechnology & Chemistry \\
\hline Field & $\begin{array}{c}\text { Social } \\
\text { Sciences }\end{array}$ & $\begin{array}{c}\text { Social } \\
\text { Sciences }\end{array}$ & $\begin{array}{c}\text { Social } \\
\text { Sciences }\end{array}$ & Humanities & Engineering & Engineering & Engineering & Sciences & Sciences & Sciences & Sciences \\
\hline Year & First & Second & Master & Fourth & Third & Third & Third & First & Second & Third & Fourth \\
\hline № students & 38 & 54 & 20 & 21 & 13 & 18 & 38 & 84 & 57 & 44 & 29 \\
\hline Product & $\begin{array}{l}\text { Oral } \\
\text { presentation } \\
\text { Final version }\end{array}$ & $\begin{array}{c}\text { Essay } \\
\text { (6 pages) } \\
\text { Draft version }\end{array}$ & $\begin{array}{c}\text { Oral } \\
\text { presentation } \\
\text { Final version } \\
\end{array}$ & $\begin{array}{c}\text { Proposal for } \\
\text { an exam } \\
\text { question and } \\
\text { answer } \\
\end{array}$ & $\begin{array}{c}\text { Oral } \\
\text { presentation } \\
\text { Final version }\end{array}$ & $\begin{array}{c}\text { Oral } \\
\text { presentation } \\
\text { Final version } \\
\end{array}$ & $\begin{array}{l}\text { Proposal for an } \\
\text { exam question }\end{array}$ & $\begin{array}{c}\text { Oral } \\
\text { presentation } \\
\text { Final version } \\
\end{array}$ & $\begin{array}{l}\text { Proposal for } \\
\text { an exam } \\
\text { question and } \\
\text { answer } \\
\end{array}$ & $\begin{array}{c}\text { Oral } \\
\text { presentation } \\
\text { Final version }\end{array}$ & $\begin{array}{c}\text { Oral } \\
\text { presentation } \\
\text { Final version } \\
\end{array}$ \\
\hline Goal & $\begin{array}{l}\text { Learning and } \\
\text { assessment }\end{array}$ & $\begin{array}{l}\text { Learning and } \\
\text { assessment }\end{array}$ & $\begin{array}{l}\text { Learning and } \\
\text { learning how } \\
\text { to assess }\end{array}$ & $\begin{array}{l}\text { Learning, } \\
\text { assessment } \\
\text { and active } \\
\text { participation }\end{array}$ & $\begin{array}{l}\text { Assessment, } \\
\text { active } \\
\text { participation }\end{array}$ & $\begin{array}{l}\text { Assessment, } \\
\text { active } \\
\text { participation }\end{array}$ & $\begin{array}{l}\text { Learning and } \\
\text { learning how to } \\
\text { assess }\end{array}$ & $\begin{array}{c}\text { Learning and } \\
\text { assessment }\end{array}$ & $\begin{array}{l}\text { Learning and } \\
\text { assessment }\end{array}$ & $\begin{array}{c}\text { Learning and } \\
\text { assessment }\end{array}$ & $\begin{array}{c}\text { Learning and } \\
\text { assessment }\end{array}$ \\
\hline Direction & $\begin{array}{l}\text { Mutual (each } \\
\text { student } \\
\text { assesses all } \\
\text { peers) }\end{array}$ & $\begin{array}{l}\text { One- } \\
\text { directional } \\
\text { (one } \\
\text { assessment } \\
\text { per student) } \\
\text { Random } \\
\text { assessee }\end{array}$ & $\begin{array}{l}\text { Mutual (each } \\
\text { group } \\
\text { assesses } \\
\text { other groups) }\end{array}$ & $\begin{array}{l}\text { Mutual (each } \\
\text { group } \\
\text { assesses the } \\
\text { response of } \\
\text { the other } \\
\text { groups to a } \\
\text { question it } \\
\text { poses) }\end{array}$ & $\begin{array}{c}\text { Mutual } \\
\text { (each student } \\
\text { assesses } \\
\text { his/her own } \\
\text { presentation } \\
\text { that of his/her } \\
\text { peers) }\end{array}$ & $\begin{array}{l}\text { Mutual } \\
\text { (each student } \\
\text { assesses all } \\
\text { peers) }\end{array}$ & $\begin{array}{l}\text { Mutual } \\
\text { (each group } \\
\text { assesses the } \\
\text { response of the } \\
\text { other groups to a } \\
\text { question it } \\
\text { poses) }\end{array}$ & $\begin{array}{c}\text { Partially } \\
\text { reciprocal } \\
\text { (each student } \\
\text { assesses the } \\
\text { work of } \\
\text { another group, } \\
\text { but not all the } \\
\text { presentations) }\end{array}$ & $\begin{array}{c}\text { Mutual } \\
\text { (each group } \\
\text { assesses the } \\
\text { response of } \\
\text { the other } \\
\text { groups to a } \\
\text { question it } \\
\text { poses) }\end{array}$ & $\begin{array}{c}\text { Mutual } \\
\text { (each student } \\
\text { assesses } \\
\text { his/her own } \\
\text { presentation } \\
\text { that of his/her } \\
\text { peers) }\end{array}$ & $\begin{array}{l}\text { Mutual } \\
\text { (each student } \\
\text { assesses } \\
\text { his/her own } \\
\text { presentation } \\
\text { that of his/her } \\
\text { peers) }\end{array}$ \\
\hline Anonymity & $\begin{array}{c}\text { Not } \\
\text { anonymous }\end{array}$ & Anonymous & $\begin{array}{c}\text { Not } \\
\text { anonymous }\end{array}$ & Anonymous & $\begin{array}{c}\text { Not } \\
\text { anonymous }\end{array}$ & $\begin{array}{c}\text { Not } \\
\text { anonymous }\end{array}$ & Not anonymous & $\begin{array}{c}\text { Not } \\
\text { anonymous }\end{array}$ & $\begin{array}{c}\text { Not } \\
\text { anonymous }\end{array}$ & $\begin{array}{c}\text { Not } \\
\text { anonymous }\end{array}$ & $\begin{array}{c}\text { Not } \\
\text { anonymous }\end{array}$ \\
\hline $\begin{array}{l}\text { Topic or } \\
\text { skill } \\
\text { assessed }\end{array}$ & $\begin{array}{l}\text { Different topic } \\
\text { Same skill }\end{array}$ & $\begin{array}{l}\text { Same (all } \\
\text { students work } \\
\text { on the same } \\
\text { topic) }\end{array}$ & $\begin{array}{l}\text { Different topic } \\
\text { Same skill }\end{array}$ & $\begin{array}{c}\text { Different } \\
\text { (each group } \\
\text { focuses on a } \\
\text { different topic) }\end{array}$ & $\begin{array}{l}\text { Different topic } \\
\text { Same skill }\end{array}$ & $\begin{array}{l}\text { Different topic } \\
\text { Same skill }\end{array}$ & $\begin{array}{l}\text { Same, each } \\
\text { group focuses } \\
\text { on the same } \\
\text { topic }\end{array}$ & $\begin{array}{l}\text { Different topic } \\
\text { Same skill }\end{array}$ & $\begin{array}{c}\text { Same, all } \\
\text { groups focus } \\
\text { on the same } \\
\text { topic } \\
\text { Same skill }\end{array}$ & $\begin{array}{l}\text { Different topic } \\
\text { Same skill }\end{array}$ & $\begin{array}{l}\text { Different topic } \\
\text { Same skill }\end{array}$ \\
\hline $\begin{array}{c}\% \text { of final } \\
\text { course mark }\end{array}$ & $1 \%$ & $7.5 \%$ & $12.5 \%$ & $5 \%$ & $5 \%$ & $10 \%$ & $9 \%$ & $10 \%$ & $5 \%$ & $10 \%$ & $3 \%$ \\
\hline
\end{tabular}


The study methodology consisted of the following steps and sub-steps:

1. Drafting (by network members) of an initial and a final questionnaire on students' perception of peer-assessment.

2. Design and implementation of peer-assessment in each subject. Within this aim, the corresponding activity was adapted to each particular subject, but taking into account the following common criteria:

- Before starting the activity, the teacher explains to students the aims of the activity and the process involved.

- The professor also describes the rubrics students will use to evaluate their peers. In most cases these rubrics are agreed with the students.

- Following the teacher's explanation, students answer the initial questionnaire (Appendix 1).

- The peer-assessment activity is performed. This can take from a few hours (oral presentations, proposal for an examination question and answers) to several days (essay).

- Upon completion of the activity, students answer the final questionnaire (Appendix 2).

3. Collection of results from initial and final questionnaires.

4. Analysis and discussion of the results obtained in the different subjects (followed by analysis and group discussion by network professors).

Since for many students it was the first time that they had assessed their peers and been assessed using rubrics, it was considered pertinent that professors explained the activity of peer-assessment in detail prior to it beginning. Several authors have found that students need to understand learning objectives adequately if they are to achieve them correctly and be able to evaluate their peers (Black and Wiliam 1998; Sadler 1989). It has also been shown that professors and students can have different conceptions not only of the objectives of an activity, but also of the evaluation criteria (Hounsell 1997; Norton 1990). It was therefore considered essential to explain the items to students in detail so that they might adopt them and apply them in a more reasoned way (Cestone, Levine and Lane 2008; Falchikov and Goldfinch 2000; Lane 2007). 
Moreover, initial and final questionnaires were designed to compare the students' perspective of peer-assessment before and after completion of the activity. Specifically, we were interested in their opinion regarding the following: their ability to participate in a peer review process, the responsibility it entails, the level of preparation required, the degree of learning achieved, subjectivity and the demands of peer-assessment compared to those on the professor, and the professor's effectiveness in explaining the activity and its design. The questionnaires were developed with a series of questions to be answered on a Likert scale of four possible responses, ranging from "1-strongly disagree" to "4strongly agree". Also, two open questions were included in both questionnaires requesting that students indicate two benefits and two limitations of the activity. The final questionnaire also included students' opinions regarding the anonymity of the activity and its influence on the development of skills useful for the future, their participation in the groupwork, and their motivation. This final questionnaire also asked students if they would recommend the use of peer-assessment in other subjects and what changes they would make. For each subject, the students' responses to the multiple choice questions were analysed quantitatively using statistical analysis, while open questions were analysed qualitatively.

\section{Results}

In general terms, the students' opinion of peer-assessment was positive, as the average score for all questions by subject was above 2.5 , and the overall average for all subjects was 2.94 (on a Likert scale of 1-4). When comparing the initial questionnaire with the final one (see Figure 1), for most subjects a greater predisposition and acceptance is observed before the activity than after it. In the initial questionnaire, the average scores for all subjects range from 2.03 to 3.92 (the average score for all means is 2.95). In the final questionnaire, on the other hand, the scores range from 1.89 to 3.89 (the average of all means being 2.92) (see Figure 2). Although there is no great difference between the global averages, a greater dispersion of scores and therefore more contrasting opinions are found among students in the final questionnaire (see Appendix 3). 
Figure 1: Mean scores for initial and final questionnaires by subject

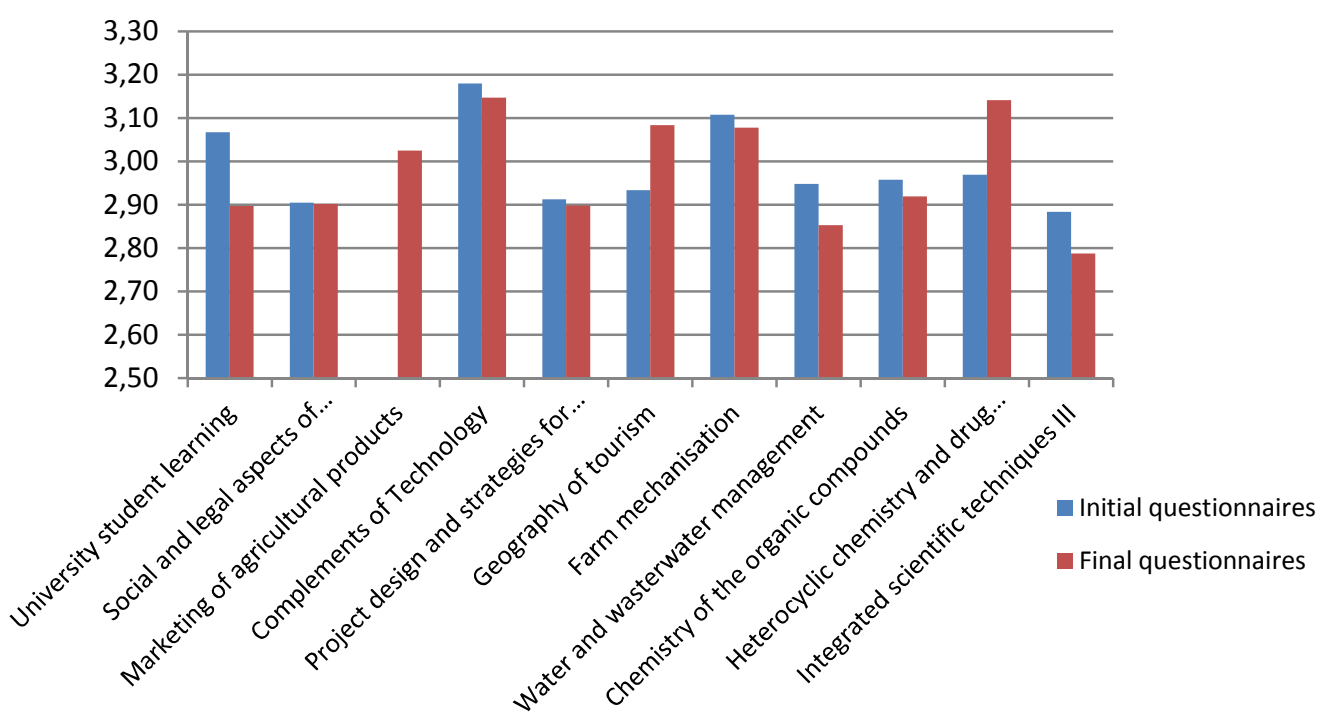

Figure 2: Boxplots of responses to the initial (P1 to P10) and final (P1 to P15) questionnaires, showing the average, maximum and minimum scores for the various questions

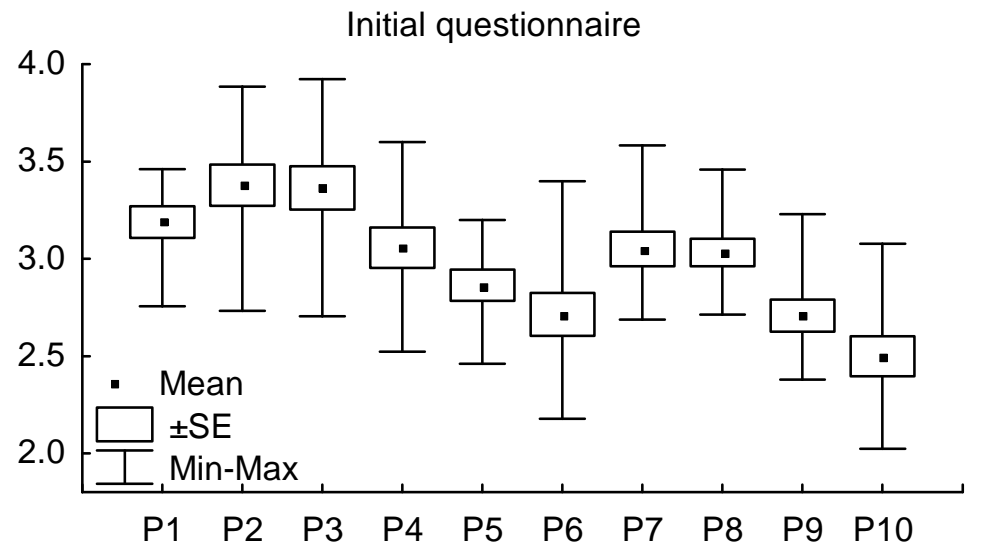




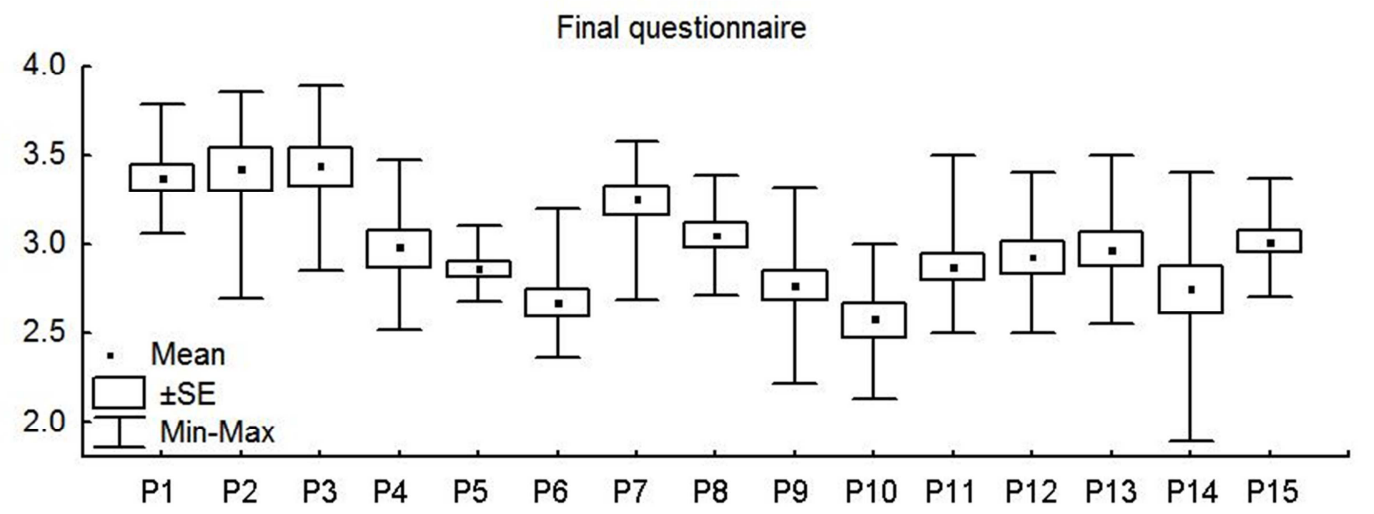

If we analyse the characteristics of the subjects at both ends of the scale in Figure 1, some clear differences are observed. On the one hand, students of Integrated Scientific Methods, scientific laboratory sessions on the first year of the Environmental Sciences degree, are more reluctant to use peer-assessment. This is attributed to the structure of the subject (working in large groups and with different professors) not allowing careful explanation of the process of peer-assessment or appropriate feedback being given to students. On the other hand, students of Complementary Technology Training on the teacher training Master's degree course show a greater predisposition towards and interest in the benefits of peer-assessment, in all probability due to their prior experience of it and the fact that this type of assessment activity will form part of their future professional work.

Although no relevant differences are found between the different subjects and students are found to generally perceive peer-assessment positively, when analysing the different elements of the process some variations are detected. The most significant of these are highlighted below.

\section{Confidence in personal abilities}

For most of the subjects, a positive trend is detected with regard to opinions on the training and skills needed to participate in a peer-assessment process (Question 1). Generally speaking, students valued being trained to participate in the peer-assessment process more after doing the activity than before starting it. Initially, they were reluctant 
to assume the responsibility to assess, alleging that a lack of experience and responsibility make it difficult for them to give a suitable mark. The subjects in which students perceived themselves as having fewer skills to participate in a peer-assessment process are the two first-year subjects and the second-year subject where they were required to conduct the assessment of a more complex product (an essay). Some of the opinions representative of this attitude given in the open answers are as follows:

"It will never be the same being corrected by a student as by a professor because the professor is assumed to be an expert in the subject matter" (Social Education degree student, initial questionnaire).

\section{Clarity of explanation and suitability of instruments}

The clarity of professors' explanations regarding the peer-assessment procedure (Question 2) and the instruments made available to students to implement it (Question 3) are highly valued by students (receiving the highest scores in both the initial and final questionnaires). Also representative of this is the fact that for both questions there was a greater unanimity of opinion (standard deviation between 0.28 and 0.88 ). The more complex the task to be carried out, the lower the scores awarded by students. It is worth noting that the lowest averages appear on the one hand in the subject where the more complex peer-assessment activity was conducted (essay correction) (Project Design and Strategies for Educational Action) and on the other in the subject with most students, practice and a larger number of professors (Integrated Scientific Techniques III). The results also indicate that both questions are evaluated less positively by first-year students than those in later years. Although most students had no previous experience of peer-assessment, those in later years have more tools and a better understanding of the university system than first-year students. We can therefore say that more attention should be given to providing tools and explaining the peer-assessment process to students in earlier than later years.

\section{Variable responsibility}

The perception of student responsibility in this assessment system varies according to the type of activity performed. Following the activity, students of subjects where the 
peer-assessment activity involved an examination or an essay in the field of social sciences and the humanities perceive greater responsibility than those conducting peerassessment with oral activities (Question 4). The activity which involved students marking an essay (Project Design and Strategies for Educational Action) is the one in which greatest responsibility was perceived ( 0.51 points higher than the average). These results might be explained by the fact that this is a complex activity in terms of preparing and mastering content, involving students qualitatively assessing their peers' essays so that they can be modified before handing them in to the professor. The more accurate the assessment, the more tools their peers will have to improve the essay and their final mark, leading to the perception that responsibility is greater in this subject than in others. Also, in peer-assessment activities in which students had to mark a test, a greater level of responsibility is perceived among humanities students than science and technology students. This is probably due to the questions posed in subjects from the latter fields requiring more objective responses than those posed in the former.

In subjects where an oral presentation is assessed, differences appear between the opinions of social sciences and science or engineering students. In the first-year social sciences subject (University Student Learning), in addition to assessing their peers students must also do a face-to-face oral presentation in class discussing the failings and areas for improvement identified in their peers' work. This requires a higher degree of commitment and responsibility than assessment that does not involve justification before assessees. The Master's subject in the field of Education (Complementary Technology Training) is designed to prepare students for their professional work in a practical way and the activity undertaken resembles one of the stages of the examination process they will face for their professional development in state education. This fosters a certain degree of "competitiveness" among students and they therefore expected a more demanding and perhaps subjective assessment from their peers than the one they actually received.

If we relate the answers to question 4 regarding perception of responsibility to the rating of peer-assessment in each subject, we find that the weight of the rating students award this form of assessment does not affect their perception of responsibility. That is, a higher percentage rating does not equate to a higher perception of responsibility. 


\section{Demanding fellow students and variable objectivity}

Questions regarding fellow students being demanding (Question 10) and the subjectivity of their assessment (Question 9) score lowest for both the initial and final questionnaires, although there is a high diversity of opinion among students.

With regard to whether students are more subjective than the professor (Question 9), the results indicate different parameters of analysis: the type of task, area of knowledge and level of knowledge among students (largely influenced by class size and year). In those assessment activities in the social sciences and humanities subjects involving more analysis and reflection (Project Design and Strategies for Educational Action, and Geography of Tourism), despite the anonymity greater subjectivity is detected. Students attributed the mark they received to a lack of objectivity on the part of their peers and competition between them. Moreover, it is observed that students perceived more objectivity in their peers in earlier years and larger groups.

In the results for Question 10 a third-year subject is worth mentioning (Social and Legal Aspects of Biotechnology) due to it having a very divided and competitive class in which students perceive their peers to be more demanding than the professor. Students perceive that when assessing, their peers do not adopt an attitude of complicity, but rather a more competitive one, even less tolerant than that of the professor(s). This view generates among some students a lack of trust in the system of peer-assessment and the quality of corrections by peers, expressed in responses to the open questions. Also, some students display insecurity regarding their ability to peer-assess, the difficulty of grading a coursemate (leading to higher scores) and a general difficulty in scoring using a rubric. It is worth considering some quotes from students to illustrate these uncertainties:

"Lack of confidence in correction by students from other groups" (Geography degree students, initial questionnaire). "Less capable of judging than the professor” (Agriculture Technical Engineering Degree students, final questionnaire). "Some criteria will not be assessed correctly" (Geography student, final questionnaire). 
Paradoxically, despite students' suspicions regarding the quality of their peers' corrections, many of them demonstrate confidence in their objectivity. However, there is a range of different opinions on this question (standard deviation between 0.66 and 0.93 in the initial questionnaire, and 0.41 and 1.07 in the final questionnaire).

\section{Learning at different levels}

In general, students stated that this activity required them to prepare their work better and seek further information regarding the contents of the module or activity (Questions 5 and 6). However, for both questions and after completing the activity, students in four subjects (three in education and one in environmental studies) stated that peerassessment helped less than expected in the preparation and doing more in-depth work. In later years (fourth year and Master's), and after finishing the activity, students perceived that peer-assessment made them prepare their work better.

With the data we have available we cannot draw too many conclusions regarding these differences. They may be attributable to the presentation of the activities creating higher expectations among these groups, the student profile being different, or these students simply engaging in the activities in the same way with or without peer-assessment.

Students also perceived that the activity helped them identify and learn from their mistakes and the mistakes of others (Question 7), as well as view their learning from a critical and constructive perspective (Question 8). The highest averages are found for the subject in which small groups (18 students) gave joint feedback after each oral presentation. The results therefore suggest that when there is face-to-face feedback students tend to become more involved and more aware of their own and others' errors. This feedback also encourages reflection and constructive criticism. In open answers students also emphasized the fact that peer-assessment improves learning outcomes and is fairer, because it is based on a set of views rather than an individual opinion (especially in those subjects where the direction of the evaluation is mutual, the technology subjects, for example). Moreover, in the subject where professor assessment takes place after modifications to peer-assessment, this system was not only useful in 
learning and improving from their own errors and mistakes and those of peers, but it also led to better grades because students were able to correct their initial exercises.

Students perceived that the peer-assessment activity helped them to develop skills that will be useful in their future careers (Question 11). High scores were observed in a social education subject (University Student Learning) in which oral communication skills are worked on throughout the course and emphasis is placed on the importance of attaining mastery of this competence as a basic tool for professionals of social education intervention. A similar trend is observed in subjects where students did oral presentations linked to practical issues and directly related to their future professional activity (Organic Heterocyclic Chemistry).

Finally, students perceived that they became more involved in groupwork (Question 12, averages between 2.5 and 3.4), especially in those subjects where they had to prepare and assess an examination as a group, and in the Master's subject, where students tend to behave like good professionals towards their peers.

\section{A motivating and recommendable system}

Students compare peer-assessment positively with the traditional assessment system (understood as assessment by written test or examination) used by professors (Question 13). Students of the subjects Complementary Technology Training and University Student Learning are those who view peer-assessment most favourably. In both of these subjects from the field of education, the peer-assessed oral presentation is the final activity in a learning process in which they have previously given other oral presentations or worked on the language of communication on a theoretical or observational level. Also, in the former case the activity is directly related to one of the activities students will perform when assessed at the end of the course (presentation of a teaching unit before a panel). In the latter, the activity takes place in small groups where students put the fundamental skills of the profession into practice. Moreover, in those subjects where the assessed activity is an examination or essay, lower average scores are obtained than those in which an oral presentation is assessed. However, a great contrast of opinions is also found here (standard deviation: 0.77 and 1.06). 
Although some reluctance is observed in some subjects, over $75 \%$ of the students who participated in the study would recommend continuation of the peer-assessment system (Question 15). Those less in favour of extending this methodology to other subjects or Master's degree courses are on the one hand students of subjects in which the peerassessment process required more commitment and effort, and on the other highly competitive groups of students.

\section{Discussion and conclusions}

Comparing the perceptions of students from different degree courses on peerassessment processes of diverse characteristics and working with a large sample provides some significant results that complement and corroborate previous research findings. In addition, this study has demonstrated the feasibility of generating usable questionnaires in eleven subjects differentiated clearly by field and type.

Students rate peer-assessment positively, considering it to motivate and facilitate learning. Stefani (1994) points out that in an experience of peer-assessment students are more motivated and interested in the activity, making them work harder than normal and enhancing the level of skills acquired. We have shown that prior to the activity students are very willing to try it, even if they do not believe they are sufficiently trained. This perception changes after doing the activity, however, when students believe they have more capabilities than they originally thought, ultimately rating it positively and recommending its use as a method of assessment. Although we cannot prove it with this particular study, observations and reflections made by participating professors lead us to consider that the more effort required to assess, the more involvement and higher the level of student performance, suggesting its great effectiveness as a training procedure.

We have also seen that students perceive it as an effective formative assessment tool for both assessor and assessee, as also acknowledged by Cestone et al. (2008), Gielen et al. (2011), and Nicol and Macfarlane-Dick (2006). Students perceive that peer-assessment has helped them to learn from their own mistakes and those of their coursemates. This 
perception increases in activities where there is face-to-face feedback between assessor and assessee. It also helps to improve marks in cases where the activity assessed by peers serves as a dry run for the final activity done before the professor.

Although not one of the items most valued by students, we would also highlight the added value of this methodology in developing skills for their future career. Hanrahan and Isaacs (2001) noted that the skills of both self and peer-assessment will be necessary for graduates in their careers (and personal life). Self-assessment helps students to set goals and thus learn for themselves. Peer-assessment will help them to contribute constructively in collaborative efforts. We also believe that the experience provides other important skills for their future professional work, such as being subjected to criticism by others of the same rank and coping with the responsibility of fairly judging the quality of a peer's work. In this regard, the student's level of responsibility in the process (by getting involved in the learning process and providing a fair assessment of their peers' work) increases with the complexity of the task and competition within the group. Greater responsibility was also observed in a face-to-face feedback process.

In spite of this positive perception of the methodology, students expressed initial anxiety towards the task, as confirmed by Levine (2008) and Topping (2009) and stress and discomfort when having their work marked by a peer (as reported by Hanrahan and Isaacs, 2001). This can be minimized by applying simple training strategies prior to the activity. We believe that the initial fears and reluctance expressed by students, deriving from a belief that they do not have enough knowledge to assess their peers and be impartial, could be minimized by means of the following simple actions:

- Giving positive feedback and explaining that peer-assessment involves learning for students and promotes a sense of personal responsibility and motivation, as posited by Topping (2009).

- Dedicating more time to agreeing on and understanding the rubrics, grade descriptors and scoring matrix prior to the assessment process (Miller 2003; Vickerman 2009).

- Analysing a case together to provide more criteria for assessment (analysing a text from the previous year, viewing an oral presentation, etc.). This means investing 
time in instructions and training to enhance students' assessment skills (Sluijsmans et al. 2002).

- Transparency in assessment processes (Taras 2009).

- The anonymity of assessors in the assessment of activities such as essays or examinations (Vickerman 2009).

- Having two or three reviewers for each assessee (in cases of one-way peerassessment).

The application of a peer-assessment system must be accompanied by a prior training process for students so that they understand the purpose of the activity and its educational value, above and beyond the mere assessing of a peer. Furthermore, different strategies should be applied when explaining the activity according to year of study and task type. In earlier years and for tasks that involve more complex analysis and reflection, more effort should be spent clarifying the activity and making tools available to students that allow them to make an objective and effective assessment. In general, however, students must be asked to display sincerity in the face of the task entrusted to them and informed that this sincerity will benefit their peers by improving their work and skills. This training and explanatory work by professors is critical, as is the importance they attribute to peer-assessment. According to Gielen et al. (2011), the importance students attribute to peer-assessment is directly related to that awarded by professors.

The low degree of learning autonomy with which some students enter the university system suggests the need for a gradual implementation of peer-assessment tools. If these tools are to be used effectively and sensibly, students require a level not only of autonomy but also of critical ability that should be practised and guided gradually. They should therefore be taught to interpret and use rubrics, argue opinions, compare information, etc. As Sluijsmans and Prins (2006, 9) point out, peer-assessment is considered a complex skill that needs to be developed, and student involvement in assessment should therefore be gradual. We believe that more research along these lines could help improve peer-assessment practices and enhance students' learning from them. 


\section{References}

Black, P. and Wiliam, D. 1998. "Assessment and classroom learning". Assessment in Education 5(1): 7-74.

Boud, D., and H. Holmes. 1995. "Self and peer marking in a large technical subject". In Enhancing learning through self assessment, ed. D. Boud 63-78. London: Kogan page.

Boyle, J. T., and Nicol, D. J. 2003. "Using classroom communication systems to support interactionand discussion in large class settings". Association for Learning Technology Journal 11(3): 43-57.

Cavas, M., Chicano, J. F., Luna, F., and Molina, L. 2010. La autoevaluación y la coevaluación como herramientas para la evaluación continua y la evaluación formativa en el marco del espacio europeo de Educación Superior. Paper presented at IV Jornadas de Innovación Educativa y Enseñanza Virtual en la Universidad de Málaga, Málaga.

Cestone, C. M., Levine, R. E., and Lane, D. R. 2008. "Peer-assessment and evaluation in team-based learning". New Directions for Teaching and Learning 116: 69-78.

De Grez, L., Valcke, M., and Roozen, I. 2012. "How effective are self- and peerassessment of oral presentation skills compared with teachers's assessments?" Active Learning in Higher Education 13 (2): 129-142

Dochy, F., Segers, M., and Sluijsmans, D. 1999. "The use of self, peer, and coassessment in higher education: a review". Studies in Higher Education 24(3): $331-350$.

Falchikov, N. 1986. "Product comparisons and process benefits of collaborative peer and self-assessments". Assessment and Evaluation in Higher Education 11: 146166.

Falchikov, N., and Goldfinch, J. 2000. "Student peer-assessment in higher education: a meta-analysis comparing peer and teacher marks". Review of Educational Research 70(3): 287-322.

Gatfield, T. 1999. "Examining student satisfaction with group projects and peerassessment". Assessment and Evaluation in Higher Education 24(4): 365-377.

Gielen, S., Dochy, F., and Onghena, P. 2011. An inventory of peer-assessment diversity, Assessment \& Evaluation in Higher Education 36 (2): 137-155. 
Gielen, S., Dochy, F., Onghena, P., Struyven, K., and Smeets, S. 2011. "Goals of peerassessment and their associated quality concepts". Studies in Higher Education 36(6): 719-735.

Hanrahan, S.J., and Isaacs, G. 2001. “Assessing self- and peer-assessment: the student's views". Higher Education Research \& Development 20(1): 53-69.

Hounsell, D. 1997. "Contrasting conceptions of essay-writing". In The experience of learning, edited by F. Marton, D. Hounsell\& N. Entwistle Edinburgh: Scottish Academic Press.

Lane, D. 2007. Engineering feedback: a student-developed approach to the assessment of peer evaluation in civil engineering. Chicago: National Communication Association.

Langan, A.M., Shuker, D.M., Cullen, W.R., Penney, D., Preziosi, R.F., and Wheater, C.P. 2008. "Relationships between student characteristics and self-, peer and tutor evaluations of oral presentations". Assessment \& Evaluation in Higher Education 33(2): 179-190.

Levine, R. E. 2008. Peer-assessment in team-based learning. In Team-based learning for health professions education: a guide to using small groups for improving learning edited by L. K. Michaelsen, D. X. Parmalee, K. K. McMahon, and R. E. Levine. Sterling: Stylus Publishing.

Lindblom-Ylänne, S.; Pihlajamäki, H., and Kotkas, T. 2006. "Self-, peer- and teacherassessment of student essays". Active learning in Higher Education 7 (1): 51-62.

Miller, P. 2003. "The Effect of Scoring Criteria Specificity on Peer and Selfassessment". Assessment and Evaluation in Higher Education 28 (4): 383-394.

Nicol, D. J., and Macfarlane-Dick, D. 2006. "Formative assessment and self-regulated learning: a model and seven principles of good feedback practice". Studies in Higher Education 31(2): 199-218.

Norton, L. S. 1990. “Essay writing: what really counts?". Higher Education 20(4): 411442.

Paswan, A. K., and Gollakota, K. 2004. "Dimensions of peer evaluation, overall satisfaction, and overall evaluation: an investigation in a group task environment". Journal of Education for Business 79(4): 275-231.

Sadler, D. R. 1989. "Formative assessment and the design of instructional systems". Instructional Science 18: 119-144. 
Sluijsmans, D., Brand-Gruwel, S., and Merriënboer, J. 2002. "Peer-assessment training in teacher education: Effects on performance and perceptions". Assessment and Evaluation in Higher Education 27 (5): 443-454.

Sluijsmans, D., and Prins, F. 2006. “A conceptual framework for integrating peerassessment in teacher education". Studies in Educational Evaluation 32 (1): 6-22.

Stefani, L. A. J. 1994. "Peer, self and tutor assessment: realitive reliabilities". Studies in Higher Education 19(1): 69-75.

Taras, M. 2009. "Summative assessment: the missing link for formative assessment". Journal of Further and Higher Education 33(1): 57-69.

Taras, M., and Davies, M.S. 2012. "Percepcions and realities in the functions and processes of assessment”. Active Learning in Higher Education 14 (1): 51-61.

Topping, K. 1998. "Peer-assessment between students in colleges and universities2. Review of Educational Research 68: 249-276.

Topping, K. 2009. "Peer-assessment”. Theory into Practice 48(1): 20-27.

Topping, K. J., Smith, E. F., Swanson, I., and Elliot, A. 2000. "Formative peerassessment of academic writing between postgraduate students". Assessment \& Evaluation in Higher Education 25(2): 149-170.

Van den Berg, I., Amiraal, W., and Pilot, A. 2007. "Peer-assessment in university teaching: evaluating seven course designs". Assessment \& Evaluation in Higher Education 31(1): 19-36.

Vickerman, P. 2009. "Student perpectives on formative peer-assessment: an attempt to deepen learning?". Assessment \& Evaluation in Higher Education 34 (2): 221230.

Wen, M.L., and Tsai Ch-Ch. 2006. "University students' perception of and attitudes toward (online) peer-assessment". Higher Education 51(1): 27-44. 


\section{Appendix 1. Initial questionnaire used to determine students' perceptions before participating in the peer-assessment process.}

Score the following statements from 1 to 4 considering that:

$1=$ strongly disagree $4=$ strongly agree

\begin{tabular}{ll|l|l}
1 & 2 & 3 & 4
\end{tabular}

1. I have the necessary skills to participate in a peer-assessment process

2. The professor(s) clearly explained the procedure for effective peerassessment

3. The professor(s) made the tools and instruments available to me to perform effective peer-assessment

4. Peer-assessment means a lot of responsibility for the student

5. Peer-assessment will make me prepare my work better

6 . Peer-assessment will force me to look for more and broader information on the contents of the module or activity

7. Peer-assessment will allow me to detect my own mistakes and learn from them

8. Peer-assessment will allow me to view learning critically and constructively

9. I think my peers will be more subjective in their assessment (not following predetermined and representative criteria for the activity being assessed) than the professor(s)

10. My peers will not be as demanding as the professor(s) in their assessment

Name two aspects you consider might be positive about this peer-assessment experience

Name two difficulties or obstacles you might find in peer-assessment 


\section{Appendix 2. Final questionnaire used to determine students' perceptions after participating in the peer-assessment process.}

Score the following statements from 1 to 4 considering that:

$1=$ strongly disagree $4=$ strongly agree

1. I had the necessary skills to participate in a peer-assessment process

2 . The professor(s) clearly explained the procedure for effective peerassessment

3. The professor(s) made the tools and instruments available to me to perform effective peer-assessment

4. Peer-assessment meant a lot of responsibility for the student

5. Peer-assessment made me prepare my work better

6. Peer-assessment forced me to look for more and broader information on the contents of the module or activity

7. Peer-assessment allowed me to detect my own mistakes and learn from them

8. Peer-assessment allowed me to view learning critically and constructively

9. I think my peers were more subjective in their assessment than the professor(s)

10. My peers were not as demanding as the professor(s) in their assessment

11. This type of assessment has helped me develop skills that will be useful to me in my future career (evaluating CVs, projects, etc.)

12. Peer-assessment made me involve myself more in groupwork

13. The peer-assessment system has proved more motivating than the traditional system of professor assessment

14. The anonymous nature of the process allows you to make comments regarding the work done

15. I would recommend this method be continued for these and other subjects of the degree course

Name two aspects you consider positive about this peer-assessment experience -

Name two difficulties or obstacles you found with the peer-assessment process $-$

What would you change about the rubrics? 
Appendix 3. Results of peer-assessment surveys (mean and standard deviation). Each question was rated on a scale of 1-4 (1: strongly disagree, 4: strongly agree).

\begin{tabular}{|c|c|c|c|c|c|c|c|c|c|c|c|c|c|c|c|c|c|c|c|}
\hline \multirow[b]{2}{*}{$\begin{array}{c}\text { Type of } \\
\text { questionnaire }\end{array}$} & \multicolumn{2}{|c|}{ 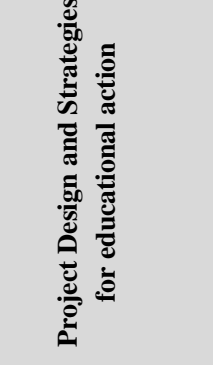 } & \multicolumn{2}{|c|}{ 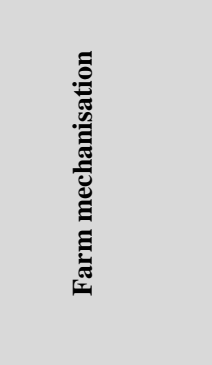 } & \multicolumn{2}{|c|}{ 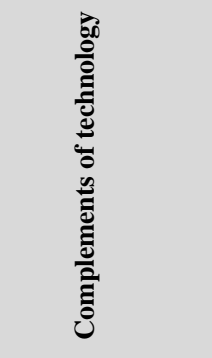 } & \multicolumn{2}{|c|}{ 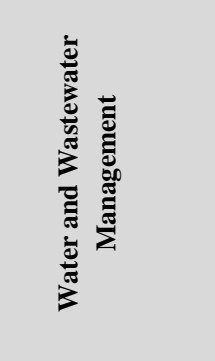 } & \multirow[t]{2}{*}{ 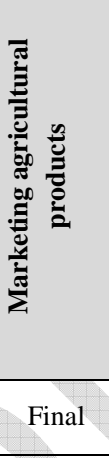 } & \multicolumn{2}{|c|}{ 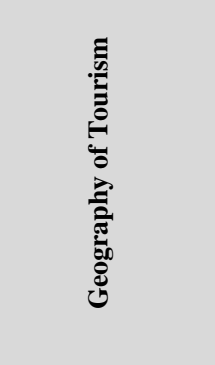 } & \multicolumn{2}{|c|}{ 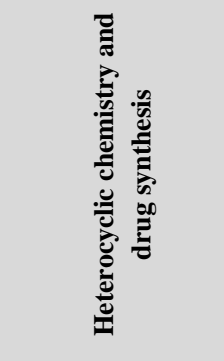 } & \multicolumn{2}{|c|}{ 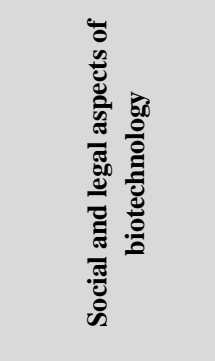 } & \multicolumn{2}{|c|}{ 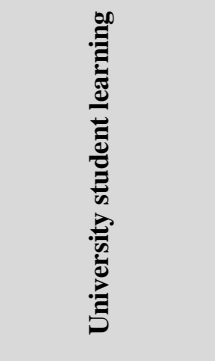 } & \multicolumn{2}{|c|}{ 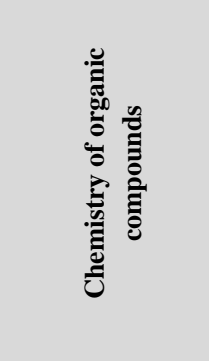 } \\
\hline & Initial & Final & Initial & Final & Initial & Final & Initial & Final & & Initial & Final & Initial & Final & Initial & Final & Initial & Final & Initial & Final \\
\hline $\mathbf{N}^{0}$ students & 45 & 49 & 13 & 12 & 5 & 5 & 32 & 35 & 18 & 21 & 20 & 26 & 27 & 39 & 47 & 39 & 20 & 57 & 28 \\
\hline 1 & $\begin{array}{c}2.76 \pm \\
0.48\end{array}$ & $\begin{array}{c}3.06 \pm \\
0.63\end{array}$ & $\begin{array}{c}3.46 \pm \\
0.78\end{array}$ & $\begin{array}{l}3.5 \pm \\
0.67\end{array}$ & $\begin{array}{l}3.2 \pm \\
0.84\end{array}$ & $\begin{array}{l}3.6 \pm \\
0.55\end{array}$ & $\begin{array}{c}3.44 \pm \\
0.72\end{array}$ & $\begin{array}{c}3.11 \pm \\
0.68\end{array}$ & $\begin{array}{c}3.78 \pm \\
0.43\end{array}$ & $\begin{array}{c}3.28 \pm \\
0.56\end{array}$ & $\begin{array}{c}3.55 \pm \\
0.6\end{array}$ & $\begin{array}{c}3.38 \pm \\
0.64\end{array}$ & $\begin{array}{c}3.52 \pm \\
0.58\end{array}$ & $\begin{array}{c}3.41 \pm \\
0.64\end{array}$ & $\begin{array}{c}3.43 \pm \\
0.62\end{array}$ & $\begin{array}{c}2.82 \pm \\
0.76\end{array}$ & $\begin{array}{c}3.10 \pm \\
0.50\end{array}$ & $\begin{array}{c}3.17 \pm \\
0.75\end{array}$ & $\begin{array}{c}3.39 \pm \\
0.74\end{array}$ \\
\hline 2 & $\begin{array}{c}2.73 \pm \\
0.72 \\
\end{array}$ & $\begin{array}{c}2.76 \pm \\
0.75 \\
\end{array}$ & $\begin{array}{c}3.54 \pm \\
0.52 \\
\end{array}$ & $\begin{array}{c}3.67 \pm \\
0.49 \\
\end{array}$ & $\begin{array}{l}3.6 \pm \\
0.55 \\
\end{array}$ & $\begin{array}{l}3.2 \pm \\
0.45 \\
\end{array}$ & $\begin{array}{l}3.5 \pm \\
0.67 \\
\end{array}$ & $\begin{array}{c}3.43 \pm \\
0.7\end{array}$ & $\begin{array}{c}3.83 \pm \\
0.38 \\
\end{array}$ & $\begin{array}{c}3.57 \pm \\
0.5\end{array}$ & $\begin{array}{c}3.75 \pm \\
0.44 \\
\end{array}$ & $\begin{array}{c}3.88 \pm \\
0.33 \\
\end{array}$ & $\begin{array}{c}3.85 \pm \\
0.46 \\
\end{array}$ & $\begin{array}{c}3.51 \pm \\
0.60 \\
\end{array}$ & $\begin{array}{c}3.72 \pm \\
0.45 \\
\end{array}$ & $\begin{array}{c}2.97 \pm \\
0.88 \\
\end{array}$ & $\begin{array}{c}3.42 \pm \\
0.60\end{array}$ & $\begin{array}{c}3.25 \pm \\
0.80 \\
\end{array}$ & $\begin{array}{c}3.29 \pm \\
0.81 \\
\end{array}$ \\
\hline 3 & $\begin{array}{l}2.7 \pm \\
0.73 \\
\end{array}$ & $\begin{array}{c}2.94 \pm \\
0.69 \\
\end{array}$ & $\begin{array}{c}3.92 \pm \\
0.28 \\
\end{array}$ & $\begin{array}{c}3.67 \pm \\
0.49 \\
\end{array}$ & $\begin{array}{l}3.4 \pm \\
0.55 \\
\end{array}$ & $\begin{array}{l}3.2 \pm \\
0.45 \\
\end{array}$ & $\begin{array}{c}3.39 \pm \\
0.76 \\
\end{array}$ & $\begin{array}{l}3.2 \pm \\
0.76\end{array}$ & $\begin{array}{c}3.76 \pm \\
0.56 \\
\end{array}$ & $\begin{array}{c}3.52 \pm \\
0.51 \\
\end{array}$ & $\begin{array}{l}3.7 \pm \\
0.47 \\
\end{array}$ & $\begin{array}{c}3.81 \pm \\
0.40 \\
\end{array}$ & $\begin{array}{c}3.89 \pm \\
0.32 \\
\end{array}$ & $\begin{array}{c}3.41 \pm \\
0.75 \\
\end{array}$ & $\begin{array}{c}3.72 \pm \\
0.62 \\
\end{array}$ & $\begin{array}{c}3.32 \pm \\
0.73 \\
\end{array}$ & $\begin{array}{c}3.63 \pm \\
0.59 \\
\end{array}$ & $\begin{array}{c}3.12 \pm \\
0.74 \\
\end{array}$ & $\begin{array}{c}3.18 \pm \\
0.72 \\
\end{array}$ \\
\hline 4 & $\begin{array}{c}3.29 \pm \\
0.69\end{array}$ & $\begin{array}{c}3.47 \pm \\
0.68\end{array}$ & $\begin{array}{c}3.08 \pm \\
0.76\end{array}$ & $\begin{array}{c}2.58 \pm \\
0.67\end{array}$ & $\begin{array}{l}3.6 \pm \\
0.89 \\
\end{array}$ & $\begin{array}{l}3.4 \pm \\
0.89 \\
\end{array}$ & $\begin{array}{c}2.59 \pm \\
0.91\end{array}$ & $\begin{array}{c}2.51 \pm \\
0.78\end{array}$ & $\begin{array}{c}2.61 \pm \\
0.78\end{array}$ & $\begin{array}{c}3.04 \pm \\
0.86\end{array}$ & $\begin{array}{l}3.3 \pm \\
0.57 \\
\end{array}$ & $\begin{array}{c}2.88 \pm \\
0.99\end{array}$ & $\begin{array}{c}3.15 \pm \\
0.82\end{array}$ & $\begin{array}{c}3.23 \pm \\
0.84\end{array}$ & $\begin{array}{c}2.96 \pm \\
0.72\end{array}$ & $\begin{array}{c}3.32 \pm \\
0.74\end{array}$ & $\begin{array}{c}3.15 \pm \\
0.87\end{array}$ & $\begin{array}{c}3.00 \pm \\
0.83\end{array}$ & $\begin{array}{c}.79 \pm \\
0.83 \\
\end{array}$ \\
\hline 5 & $\begin{array}{c}2.91 \pm \\
0.85\end{array}$ & $\begin{array}{c}2.69 \pm \\
0.87\end{array}$ & $\begin{array}{c}2.46 \pm \\
0.97\end{array}$ & $\begin{array}{c}2.75 \pm \\
0.75\end{array}$ & $\begin{array}{l}3.2 \pm \\
0.84 \\
\end{array}$ & $\begin{array}{c}3 \pm \\
0.71 \\
\end{array}$ & $\begin{array}{c}2.59 \pm \\
0.84\end{array}$ & $\begin{array}{c}2.91 \pm \\
0.63\end{array}$ & $\begin{array}{c}2.78 \pm \\
0.94\end{array}$ & $\begin{array}{c}3.19 \pm \\
0.83\end{array}$ & $\begin{array}{l}3.1 \pm \\
0.72 \\
\end{array}$ & $\begin{array}{c}2.81 \pm \\
0.98\end{array}$ & $\begin{array}{c}2.96 \pm \\
0.76\end{array}$ & $\begin{array}{c}2.56 \pm \\
0.97 \\
\end{array}$ & $\begin{array}{c}2.68 \pm \\
1.00 \\
\end{array}$ & $\begin{array}{c}3.05 \pm \\
0.74 \\
\end{array}$ & $\begin{array}{c}2.85 \pm \\
0.74 \\
\end{array}$ & $\begin{array}{c}3.07 \pm \\
0.96 \\
\end{array}$ & $\begin{array}{c}2.93 \pm \\
0.90 \\
\end{array}$ \\
\hline 6 & $\begin{array}{c}2.84 \pm \\
0.85\end{array}$ & $\begin{array}{c}2.49 \pm \\
0.89\end{array}$ & $\begin{array}{c}2.54 \pm \\
0.97\end{array}$ & $\begin{array}{c}2.67 \pm \\
0.78\end{array}$ & $\begin{array}{l}3.4 \pm \\
0.55\end{array}$ & $\begin{array}{l}3.2 \pm \\
0.45\end{array}$ & $\begin{array}{c}2.94 \pm \\
0.72\end{array}$ & $\begin{array}{c}2.94 \pm \\
0.84\end{array}$ & $\begin{array}{c}2.67 \pm \\
0.97\end{array}$ & $\begin{array}{c}2.52 \pm \\
0.81\end{array}$ & $\begin{array}{c}2.55 \pm \\
0.76\end{array}$ & $\begin{array}{c}2.38 \pm \\
0.85\end{array}$ & $\begin{array}{c}2.67 \pm \\
1.04\end{array}$ & $\begin{array}{c}2.18 \pm \\
0.64\end{array}$ & $\begin{array}{c}2.36 \pm \\
0.92\end{array}$ & $\begin{array}{c}2.89 \pm \\
0.72 \\
\end{array}$ & $\begin{array}{c}2.45 \pm \\
0.99\end{array}$ & $\begin{array}{c}2.81 \pm \\
0.90 \\
\end{array}$ & $\begin{array}{c}2.93 \pm \\
0.81 \\
\end{array}$ \\
\hline 7 & $\begin{array}{c}3.24 \pm \\
0.68\end{array}$ & $\begin{array}{c}3.33 \pm \\
0.69\end{array}$ & $\begin{array}{c}3.08 \pm \\
0.95\end{array}$ & $\begin{array}{l}3.5 \pm \\
0.52\end{array}$ & $\begin{array}{l}2.8 \pm \\
0.45 \\
\end{array}$ & $\begin{array}{l}3.4 \pm \\
0.55 \\
\end{array}$ & $\begin{array}{c}2.69 \pm \\
0.74\end{array}$ & $\begin{array}{c}2.69 \pm \\
0.83 \\
\end{array}$ & $\begin{array}{c}3.39 \pm \\
0.61\end{array}$ & $\begin{array}{c}3.19 \pm \\
0.62\end{array}$ & $\begin{array}{c}3.15 \pm \\
0.67 \\
\end{array}$ & $\begin{array}{c}2.92 \pm \\
0.80\end{array}$ & $\begin{array}{c}3.48 \pm \\
0.64\end{array}$ & $\begin{array}{c}2.69 \pm \\
0.98\end{array}$ & $\begin{array}{c}2.96 \pm \\
0.72 \\
\end{array}$ & $\begin{array}{c}3.58 \pm \\
0.69\end{array}$ & $\begin{array}{c}3.58 \pm \\
0.69 \\
\end{array}$ & $\begin{array}{c}3.15 \pm \\
0.89\end{array}$ & $\begin{array}{c}3.14 \pm \\
0.80 \\
\end{array}$ \\
\hline 8 & $\begin{array}{c}3.13 \pm \\
0.63\end{array}$ & $\begin{array}{c}2.98 \pm \\
0.75\end{array}$ & $\begin{array}{c}3.23 \pm \\
0.44\end{array}$ & $\begin{array}{c}3.33 \pm \\
0.49\end{array}$ & $\begin{array}{c}3 \pm \\
0.71\end{array}$ & $\begin{array}{l}2.8 \pm \\
0.45\end{array}$ & $\begin{array}{c}2.94 \pm \\
0.56\end{array}$ & $\begin{array}{c}2.71 \pm \\
0.71\end{array}$ & $\begin{array}{c}3.06 \pm \\
0.8\end{array}$ & $\begin{array}{c}2.8 \pm \\
0.71\end{array}$ & $\begin{array}{c}3.05 \pm \\
0.6\end{array}$ & $\begin{array}{c}2.85 \pm \\
0.73\end{array}$ & $\begin{array}{c}3.33 \pm \\
0.78\end{array}$ & $\begin{array}{c}2.79 \pm \\
0.77\end{array}$ & $\begin{array}{c}2.83 \pm \\
0.79\end{array}$ & $\begin{array}{c}3.46 \pm \\
0.64\end{array}$ & $\begin{array}{c}3.39 \pm \\
0.50\end{array}$ & $\begin{array}{c}3.10 \pm \\
0.69\end{array}$ & $\begin{array}{c}3.04 \pm \\
0.69\end{array}$ \\
\hline 9 & $\begin{array}{c}2.8 \pm \\
0.66\end{array}$ & $\begin{array}{c}2.7 \pm \\
0.98\end{array}$ & $\begin{array}{c}2.69 \pm \\
0.85\end{array}$ & $\begin{array}{c}2.92 \pm \\
0.79\end{array}$ & $\begin{array}{c}3 \pm \\
0.71\end{array}$ & $\begin{array}{l}2.6 \pm \\
0.55\end{array}$ & $\begin{array}{c}2.69 \pm \\
0.82\end{array}$ & $\begin{array}{c}2.69 \pm \\
0.96\end{array}$ & $\begin{array}{c}2.89 \pm \\
0.76\end{array}$ & $\begin{array}{c}2.38 \pm \\
0.92\end{array}$ & $\begin{array}{c}2.8 \pm \\
0.95\end{array}$ & $\begin{array}{c}2.69 \pm \\
0.93\end{array}$ & $\begin{array}{c}2.96 \pm \\
0.90\end{array}$ & $\begin{array}{c}3.23 \pm \\
0.84\end{array}$ & $\begin{array}{c}3.32 \pm \\
0.73\end{array}$ & $\begin{array}{c}2.70 \pm \\
0.90\end{array}$ & $\begin{array}{c}2.80 \pm \\
0.41\end{array}$ & $\begin{array}{c}2.46 \pm \\
0.84\end{array}$ & $\begin{array}{c}2.21 \pm \\
1.07\end{array}$ \\
\hline 10 & $\begin{array}{c}2.71 \pm \\
0.87\end{array}$ & $\begin{array}{c}2.61 \pm \\
1\end{array}$ & $\begin{array}{c}3.08 \pm \\
0.86\end{array}$ & $\begin{array}{c}3 \pm \\
1.04\end{array}$ & $\begin{array}{c}2.6 \pm \\
0.89\end{array}$ & $\begin{array}{c}3 \pm \\
0.71\end{array}$ & $\begin{array}{c}2.72 \pm \\
0.96\end{array}$ & $\begin{array}{c}2.76 \pm \\
0.92\end{array}$ & $\begin{array}{c}2.89 \pm \\
0.83\end{array}$ & $\begin{array}{c}2.19 \pm \\
0.6\end{array}$ & $\begin{array}{c}2.25 \pm \\
0.79\end{array}$ & $\begin{array}{c}2.08 \pm \\
1.06\end{array}$ & $\begin{array}{c}2.37 \pm \\
0.74\end{array}$ & $\begin{array}{c}2.03 \pm \\
0.99\end{array}$ & $\begin{array}{c}2.13 \pm \\
0.92\end{array}$ & $\begin{array}{c}2.55 \pm \\
0.97\end{array}$ & $\begin{array}{c}2.45 \pm \\
0.82\end{array}$ & $\begin{array}{c}2.44 \pm \\
1.05\end{array}$ & $\begin{array}{c}2.14 \pm \\
1.04\end{array}$ \\
\hline
\end{tabular}




\begin{tabular}{|c|c|c|c|c|c|c|c|c|c|c|}
\hline 11 & $\begin{array}{c}2.8 \pm \\
0.54 \\
\end{array}$ & $\begin{array}{c}2.92 \pm \\
0.79 \\
\end{array}$ & $\begin{array}{c}2.8 \pm \\
0.45 \\
\end{array}$ & $\begin{array}{c}2.63 \pm \\
0.6 \\
\end{array}$ & $\begin{array}{c}3 \pm \\
0.84 \\
\end{array}$ & $\begin{array}{c}2.85 \pm \\
0.93 \\
\end{array}$ & $\begin{array}{c}3.00 \pm \\
0.78 \\
\end{array}$ & $\begin{array}{c}2.83 \pm \\
0.82 \\
\end{array}$ & $\begin{array}{c}3.50 \pm \\
0.51 \\
\end{array}$ & $\begin{array}{c}2.50 \pm \\
0.75 \\
\end{array}$ \\
\hline 12 & $\begin{array}{c}2.67 \pm \\
0.83\end{array}$ & $\begin{array}{c}3 \pm \\
0.74\end{array}$ & $\begin{array}{c}3.2 \pm \\
0.84\end{array}$ & $\begin{array}{c}3 \pm \\
0.73\end{array}$ & $\begin{array}{c}2.5 \pm \\
0.86\end{array}$ & $\begin{array}{c}3.4 \pm \\
0.68\end{array}$ & $\begin{array}{c}2.96 \pm \\
0.76\end{array}$ & $\begin{array}{c}2.55 \pm \\
1.02\end{array}$ & & $\begin{array}{c}3.18 \pm \\
0.55\end{array}$ \\
\hline 13 & $\begin{array}{c}2.69 \pm \\
0.88\end{array}$ & $\begin{array}{c}3.17 \pm \\
0.94\end{array}$ & $\begin{array}{c}3.4 \pm \\
0.89\end{array}$ & $\begin{array}{c}2.71 \pm \\
0.99\end{array}$ & $\begin{array}{c}3.17 \pm \\
0.92\end{array}$ & $\begin{array}{c}2.8 \pm \\
1.06\end{array}$ & $\begin{array}{c}2.85 \pm \\
0.91\end{array}$ & $\begin{array}{c}2.55 \pm \\
1.00\end{array}$ & $\begin{array}{c}3.50 \pm \\
0.68\end{array}$ & $\begin{array}{c}3.00 \pm \\
0.77\end{array}$ \\
\hline 14 & $\begin{array}{c}3.39 \pm \\
0.76\end{array}$ & $\begin{array}{c}2.58 \pm \\
1\end{array}$ & $\begin{array}{c}3.4 \pm \\
0.55\end{array}$ & $\begin{array}{c}2.71 \pm \\
0.96\end{array}$ & $\begin{array}{c}1.89 \pm \\
1.13\end{array}$ & $\begin{array}{c}2.8 \pm \\
0.77\end{array}$ & $\begin{array}{c}2.93 \pm \\
0.87\end{array}$ & $\begin{array}{c}2.79 \pm \\
0.86\end{array}$ & $\begin{array}{c}2.26 \pm \\
0.93\end{array}$ & $\begin{array}{c}3.00 \pm \\
0.90\end{array}$ \\
\hline 15 & $\begin{array}{c}2.9 \pm \\
0.74\end{array}$ & $\begin{array}{c}2.92 \pm \\
0.9\end{array}$ & $\begin{array}{c}3 \pm \\
0.71\end{array}$ & $\begin{array}{c}2.77 \pm \\
0.81\end{array}$ & $\begin{array}{c}3.17 \pm \\
0.92\end{array}$ & $\begin{array}{l}3.2 \pm \\
0.83\end{array}$ & $\begin{array}{c}3.19 \pm \\
0.92\end{array}$ & $\begin{array}{c}2.70 \pm \\
1.02\end{array}$ & $\begin{array}{c}3.37 \pm \\
0.49\end{array}$ & $\begin{array}{c}3.07 \pm \\
0.66\end{array}$ \\
\hline
\end{tabular}

${ }^{a}$ No initial survey responses are available for the subject "Marketing Agricultural Products" 


\section{Bionotes}

Anna Planas is a Lecturer in the Department of Pedagogy at the University of Girona. She has a background in community development and worked in the voluntary sector and youth and cultural services of local government before joining the University. Her research interests include community development, assessment, and youth and cultural policies. In the educational field she has published research on quality improvement in education and student participation in university governance.

Lidia Feliu obtained a BSc degree in Pharmacy from the University of Barcelona, where she began her scientific career and completed her PhD degree in 2000. In 2001, she obtained a two-year postdoctoral position at the University of Montpellier as Marie Curie Fellow. Following that, she moved to the University of Girona, where she obtained a Marie Curie Reintegration Grant. She joined the Department of Chemistry's LIPPSO group as lecturer and became Associate Professor in 2008. Her main research topics are centered on the design and synthesis of peptides with antimicrobial and antitumor activity.

Rosa Maria Fraguell obtained a $\mathrm{PhD}$ in Human Geography from the Autonomous University of Barcelona in 1994. She is a Professor of Geography and Tourism Studies at the University of Girona. Her research focuses on spatial analysis in tourism, in particular strategy design for the integrated management and sustainable development of tourist destinations, topics on which he has a number of scientific publications.

Gerard Arbat is a Lecturer in the Department of Chemical and Agricultural Engineering and Food Technology at the University of Girona. His research field is centered on soil water modeling under different irrigation systems, water re-use in agriculture and optimization of irrigation systems in public parks and gardens. He is the author of several scientific papers dealing with these topics.

Joan Pujol graduated as an agronomist from the University of Lleida in 1995. In 2003, he obtained his doctorate from the University of Córdoba. The following year he was a visiting researcher for three months at the Facoltà di Agraria, Università di Bologna (Italy). He has taught at the University of Girona's Polytechnic School since 1994, and is currently contracted as a permanent collaborator in the Department of Chemical and Agricultural Engineering and Food Technology. His research has focused on issues relating to the economy of natural resources, particularly water.

Núria Roura-Pascual is an Associate Professor at the Department of Environmental Sciences of the University of Girona. She studies the causes and consequences of biological invasions, with special emphasis on ant species.

Joan Josep Suñol is Full Professor of Applied Physics at the University of Girona. His field of specialization is the production as well as the thermal and structural characterization of new materials. He has published over 120 scientific articles and has more than 150 conference papers. He is coauthor of 8 university physics books and a member of the Royal Spanish Society of Physics' specialist physics education group. 
Lino Montoro Moreno obtained a PhD in chemical engineering from the Polytechnical University of Valencia in 2005. He has been a lecturer in fluid mechanics at the University of Girona since 2006. His research interests include the use of CFD (computational fluid dynamics) as a tool for industrial equipment design and optimization; he also works in the areas of machine condition monitoring, lubrication, and oil analysis. 